\title{
-
}

\section{SIMBOL LANGUAGE IN LEARNING MATH IN SCHOOL}

\author{
Azis $^{1)}$, Maya Nurlita ${ }^{2)}$ \\ Dayanu Ikhsanuddin University ${ }^{1), 2)}$ \\ Email: azis nasam@yahoo.com ${ }^{1)}$, maya nurlita@ymail.com ${ }^{2)}$
}

\begin{abstract}
The purpose of this paper is to describe the symbol language in learning mathematics in school. To communicate a concept especially in the learning of mathematics required a symbol that is the language of symbols. Symbols are images, shapes, or objects that represent an idea or number of things. Without the meaning attached to it, the symbols on mathematics become meaningless, and dry to meaning. Mathematics itself is a language, meaning that mathematics is not just a tool of thought, a tool to find patterns, but also as a vehicle for communication between students and communication between teachers and students, where the math there are symbols. In communicating the meaning of the symbols many things that need to be considered by the teacher, such as the diversity of characteristics of students in the class, so that the meaning of the symbol can be up to the students.
\end{abstract}

Keywords: language, symbol, math school

\section{INTRODUCTION}

Language is an important communication tool for everyone so that the parties within the scope of the communication become aware of what is being said and what is being said. According Keraf in Smarapradhipa (2005, p.1), gives two terms of language. First sense states the language as a means of communication between members of the public in the form of sound symbols produced by human speech utensils. Second, language is a communication system that uses vowel symbols (speech sounds) that are arbitrary. In the process of learning in school, language is an important factor to make the interaction between teachers and students. When this interaction occurs it will be a process of mutual understanding and this can be a diagnosis for teachers and students to understand the shortcomings and advantages over the ability it has. Mathematics as a tool for other science is well known and has no doubt. Mathematics is not just a tool for science, but more than that math is a language.

Mathematics is a language that represents a set of meaningful statements that we want to convey. In line with that Herdian (2010) said that mathematics is a language, this means that math is a way of expressing or explaining in a certain way. In this case that is used by the language of mathematics is to use symbols. Although math (including those taught in schools) is a symbol language, the benefits of the symbols are really important. 
When students feel the usefulness of the use of mathematical symbols, of course he will appreciate (lesson) mathematics.

Rubenstein et al. (2001) describes some of the functions of symbols in mathematics: 1) describing mathematical structures, by understanding mathematical symbols, we become more comprehending of structure more broadly and comprehensively; 2 ) help make routine manipulation, math skills using math symbols help us deal with problems quickly and automatically without losing meaning; 3) enabling reflective activities in mathematics, including awareness of the schema and concepts it possesses, understanding relationships and structures, and manipulating it in various ways, and 4) accommodating the neatness and mind-bending, the mathematical symbol itself is a steady one agreed upon by mathematicians. By using these same mathematical symbols, our way of thinking becomes neater and easier.

It should be understood that in mathematics the symbols are not limited to symbols or notations $(1, \Pi, \%$, and so on) but also terminology (square, height, matrix, tribe, prime, and so on). Thus, the high term in mathematics differs from the high term in geophysics (or physics) everyday. While according to Skemp (1971, p.68) the function of the symbol namely:

1. Communication

2. Recording Knowledge

3. The Formation of New Concept

4. Making Multiple Straightforward

5. Explanation

6. Making Possible Reflective Activity

7. Helping to Show Structure

8. Making Automatic Routine Manipulation

9. Recovering Information and Understanding

10. Creative Mental Activity

In this paper will discuss one of the functions of symbols in the learning of mathematics symbols as a means of communication. According to Wahyudin (2008, p.527) communication is an essential part of mathematics and mathematics education. The process of communication also helps build meaning and persistence for ideas and make the idea known to the public, especially students at the time of learning mathematics. The purpose of this paper is to describe the symbol language in learning mathematics in school.

\section{DISCUSSION}

Symbols are derived from the Greek word symballo. Symbolo means throwing together, throwing or putting together in one idea or concept of the visible object, so that the object represents the idea. According to William Dillistone (in Masbied), symbols are images of a real object or imagination that evokes feelings or is aroused by feelings. Feelings associated with objects, with each other and with the subject. Meanwhile, according to Ansari, the symbol is a sign to indicate the relationship with the reference in a convention or mutual agreement, for example is the language (verbal, non verbal, or written), and also objects that represent an existence that has traditionally been agreed. 
According to Skemp (1979, p.69) the symbol is a sound or something to be seen, which is mentally related to an idea. This idea is what the symbol means. Without an idea attached to it, then the symbol has no meaning. The symbol and its meaning must be accepted as a whole. So, in general symbols are images, shapes, or objects that represent an idea, idea, or number of things. Although the symbol is not the value itself, the symbol is necessary for the purpose of appreciating the values it represents. Symbols can be used for any purpose. For example science, social life, also religious. Symbols form not only in the form of visible objects, but also through movement and speech. Symbols also serve as one of the language infrastructure, known as symbol language. The most common symbol is writing, which is a symbol of words and sounds.

Soedjadi (2007, p.13) argues that the symbols in mathematics are generally still empty of meaning so that it can be given meaning according to the scope of the universe. The symbols of mathematics are new artificially meaning after a meaning has been given to it, without which mathematics is merely a collection of dry or meaningless formulas or symbols. In connection with this, we often encounter in life, many people say that $X, Y, Z$ it has absolutely no meaning. For symbols to mean then we must understand the ideas contained in the symbol. Therefore, the most important thing is that the idea must be understood before the idea itself is symbolized. For example the symbol $(x, y)$ is a pair of symbols " $x$ " and " $y$ " which are still empty of meaning. If the concept is used in analytic geometry of the field, it can be interpreted as the point coordinate, for example $A(1,2), B$ (6.9), point $A(1,2)$ point $A$ lies in the intersection of lines $x=1$ and $y=2$ Point $B(6.9)$ means point $B$ lies on the intersection of lines $x=6$ and $y=9$. The relationships with the symbols and then apply the concepts resulting in a real conformation. Therefore, in learning, especially mathematics, the process of communicating a good symbol by the teacher to the student becomes very important.

The types of symbols in mathematics:

1. Symbols for numbers, quantities, variables (or variables) or objects. Entering this category is a symbol of trigonometric functions, ranks, roots, logarithms or symbols to fund the variables.

2. Operating symbols that describe operations against numbers. Entering this category are: addition, subtraction, division, multiplication, and symbols in set, factorial, integral and differential.

3. The symbols of relationships that describe something are defined. Symbols equal to (=) and inequality (<and>), ratio (ratio).

Mathematics is a language, meaning that mathematics is not just a thinking tool, a tool for finding patterns, but also as a vehicle for communication between students and communication between teachers and students. Communication in mathematics and mathematics learning becomes necessary as revealed by Lindquist (in Masbied), if we agree that mathematics is a language and language as the best discussion in the community, it is easy to understand that communication is the essence and teaching, learning, And access math.

Communication is a very important part of mathematics education. Communication is a way of sharing ideas and clarifying comprehension. Through communication ideas can be mirrored, improved, discussed, and developed. The process of communication also helps build meaning and embed the ideas and communication process can also publish ideas. 
When students are challenged by their thoughts and thinking skills about mathematics and communicating their thoughts orally or in writing, they are learning to explain and convince. Listening to other students' explanations, giving students the opportunity to develop their understanding (NCTM: 2000).

Sudrajat (in Masbied) says when a student gets information in the form of mathematical concepts given by teachers as well as obtained and readings, then when it happens the transformation of mathematical information and resources to the student. Students will respond according to their interpretation of the information. The problem that often arises is the response given by the students to the information they received does not match what is expected. This may be due to characteristics and mathematics laden with terms and symbols, so it is not uncommon to have students who are able to solve math problems well, but do not understand what he is doing.

The concept is an abstract mental object in one's mind that can not be heard and seen. Since the teacher cannot directly observe one's mind, a symbol is needed. The willingness of a symbol connected to a similar concept in mind $A$ and mind $B$ then by pronouncing the symbol, A can generate concepts from memory B into consciousness. Can cause him to think of new concepts. This is however not an easy one, since it is also possible that $B$ misquoted information from $A$ then the possibility of $B$ may alter the concept conveyed by $A$. So when a mathematical information concept is given by a teacher to the student or the student gets it by reading, Then when it is going on transformation of mathematical information from communicator to communicant. The response given by the communicant is the interpretation of the communicant about the information. In mathematics, the quality of interpretation and response is often a special issue. This is as a result of the characteristics of mathematics itself laden with terms and symbols. Therefore, the ability to communicate in mathematics becomes a special demand.

In communicating the meaning of the symbol of a teacher can perform both verbal and visual communication, it is expected that the symbol's meaning given by the teacher can be up to the students so that between teacher and students have the same perception about the meaning or meaning of a symbol. Many things need to be considered by teachers in conveying the meaning of symbols to students, such as differences or diversity characteristics in the classroom. In the classroom there are three groups of listeners or readers, namely: 1 . listener (student) does not know what is being said, but he is interested, 2. The listener knows what is commonly spoken about 3 . The listener already knows what is being said, but wants to drop / by finding a gap.

In order for the three groups can be embraced especially for the third class then in the learning process the teacher should highlight the benefits of the symbol so that students become more interested to follow the learning process and in a conversation, the teacher should not use the same symbol with different meanings, Confusing the students.

\section{CONCLUSION}

To communicate a concept especially in the learning of mathematics required a symbol that is the language of symbols. Symbols are images, shapes, or objects that represent an idea, idea, or number of things. Without the meaning attached to it, the symbols on mathematics become meaningless, and dry to meaning. Mathematics itself is a language, meaning that 
mathematics is not just a tool of thought, a tool to find patterns, but also as a vehicle for communication between students and communication between teachers and students, where the math there are symbols. In communicating the meaning of the symbols, many things need to be considered by the teacher, such as the diversity of characteristics of students in the class, so that the meaning of the symbol can be up to the students.

\section{REFFERENCES}

1) Ansari, I.B. 2009. Komunikasi Matematik Konsep dan Aplikasi. Banda Aceh: Yayasan Pena.

2) Gray, E., \& Tall, D. 1994. Duality, Ambiguity and Flexilbility: A Proceptual View of Simple Arithmetics. The Journal for Research in Mathematics Education. Vol 26 (2).

3) Herdian. 2010. Kemampuan Komunikasi Matematika. diakses pada http://herdy07_wordpress.com pada tanggal 1 April 2013.

4) Masbied. 2010. Cara Seseorang Memperoleh Pengetahuan dan Implikasinya Pada Pemebalajaran Matematika. diakses pada http://www.masbied.com/2010/03/20/caraseseorang-memperoleh-pengetahuan-dan-implikasinya-pada-pembelajaranmatematika/\#more-2473. pada tanggal 1 April 2013.

5) NCTM. 2000. Principles and Standards for School Mathematics. Reston: NCTM Peraturan Menteri Nomor 23 Tahun 2006 Tentang Standar Kompetensi Lulusan.

6) Nizar, A. 2007. Kontribusi Matematika dalam Membangun Daya Nalar dan Komunikasi Siswa. diakses pada http://n124r.wordpress.com/2007/08/17/acmadnizar/ pada tanggal 2 April 2013.

7) Rubenstein \& Thompson. 2001. Learning Mathematical Symbolism: Challenges and Instructional Strategies" dalam Mathematics Teacher. Volume 94 Number 4 (April 2001).

8) Skemp, R.R. 1971. The Psychology of Learning Matemathics. University of Warwich School Education.

9) Soedjadi, R. 2007. Masalah Kontekstual Sebagai Batu Sendi Matematika Sekolah. Surabaya: PSMS UNESA.

10)Wahyudin. 2008. Pembelajaran dan Model-Model Pembelajaran. Jakarta: CV. Ipa Abong. 